\title{
9 Electromagnetic Fields Mitigate Adverse Effects of Environmental Stresses in Plants
}

\author{
Angel De Souza-Torres \\ Granma University
}

\section{CONTENTS}

Introduction. 101

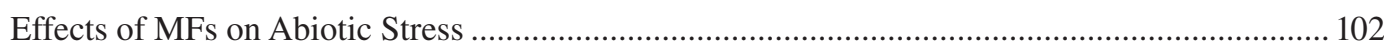

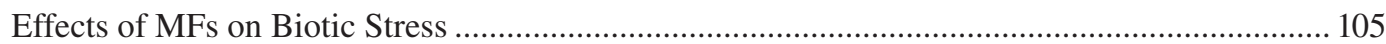

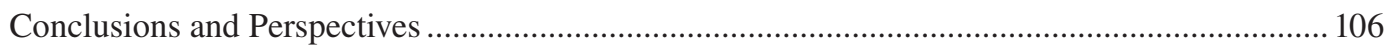

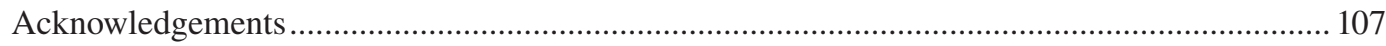

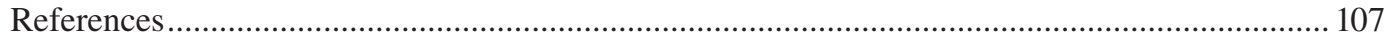

\section{INTRODUCTION}

This chapter provides a state-of-the-art overview of the mitigating effects of electromagnetic fields (EMFs) on plants sown under abiotic and biotic stresses and thus their implications for agroecology. It considers static and alternating magnetic fields (MFs) and pulsed fields (PEMFs) ranging from $1.5 \mu \mathrm{T}$ up to $800 \mathrm{mT}$ in the range of extremely low frequencies $(0-300 \mathrm{~Hz})$.

Environmental stress may be defined as an adverse external condition for plant growth and development or productivity of plants, caused by either environmental or biological factors, or both (Verma et al., 2013). Plant stress can be divided into two main categories: abiotic stress and biotic stress. Abiotic stress imposed on plants by the environment may be either physical or chemical (drought, salinity, high temperatures, ultraviolet light, heavy metal toxicity), while biotic stress imposed on plants is a biological factor such as insects, bacteria, viruses, pathogens and weeds (Gull et al., 2019; Verma et al., 2013). Exposure of plants to biotic and abiotic stress induces a disruption in plant metabolism, implying physiological costs (Bolton, 2009; Heil and Bostock, 2002; Massad, et al., 2012; Swarbrick et al., 2006), and thus leading to a reduction in fitness and ultimately in productivity (Shao et al., 2008). Abiotic stress has a great impact on plant growth by causing growth reductions of up to $50 \%$ in most plant species and, consequently, is responsible for severe losses in the field (Wang et al., 2003). Still, biotic stress is an additional challenge, inducing a strong pressure on the plant and adding to this damage through pathogen, pest, insect or herbivore attack (Brown and Hovmoller, 2002; Maron and Crone, 2006; Mordecai, 2011; Strauss and Zangerl, 2002). Under natural conditions, concurrent occurrence of two or more different types of stresses, such as drought and salinity, is more detrimental to global crop production (Pandey et al., 2015; Prasch and Sonnewald, 2013; Suzuki et al., 2014). The nature of the interactions between the abiotic and biotic stresses and the duration of stress exposure can lead to a series of effects on plant growth, development and overall yield and also determine the extent of the influence on crop productivity. 
It is predicted that, with climate change and especially global warming, environmental stresses will become more intense and frequent in the future. Therefore, maintaining crop yields under adverse environmental stresses is one of the major challenges facing modern agriculture, and plants might react to environmental stress on several levels: on the biochemical, cellular or morphological scale, and at species or population level. However, different studies suggest that static and alternating MFs and PEMFs prevent the huge injuries of abiotic and biotic stresses on agricultural crops and other economically important plants and play a role in triggering plant defence responses and antioxidant defence systems by reducing the oxidative damage in plants caused by stress situations (Anand et al., 2012; Baby et al., 2011; Baghel et al., 2018; Chen et al., 2017; Javed et al., 2011; Karimi et al., 2017; Ruzic and Jerman, 2002; Radhakrishnan et al., 2012; Sen and Alikamanoglu, 2016; Trebbi et al., 2007; Shine and Guruprasad, 2012; Shine et al., 2012).

\section{EFFECTS OF MFS ON ABIOTIC STRESS}

Abiotic stress exerts a negative impact on the growth rate and reproduction of a plant (Gull et al., 2019). Drought, salinity, heavy metal toxicity, ultraviolet light and low and high temperatures are examples of abiotic stress factors. It has been claimed that abiotic stress causes the most crop loss of any other factor, causing most major crops to have over 50\% lower yields than their potential (Fahad et al., 2017).

Several studies have shown that a magnetic treatment at pre-sowing alleviated the adverse effects of drought, salinity, heavy metal toxicity, ultraviolet light and high temperatures or heat stress in some plant species (Table 9.1).

The results of several investigations indicate that MF can provide protection against the adverse effects of drought stress. For example, when common fig (Ficus carica L., cv. Sabz) nodal explants were subjected to static MF of $170 \mathrm{mT}$ for 15, 30 and $60 \mathrm{~min}$ every day under drought stress (three concentrations of polyethylene glycol 6000 (PEG): 0,3 and 6\%w/v) in vitro conditions, a protective

TABLE 9.1

\section{Examples of Effects of Electromagnetic Fields of Plants Sown under Abiotic Stress} Conditions

\begin{tabular}{|c|c|c|c|c|}
\hline \multirow[b]{2}{*}{ Plant Species } & \multicolumn{2}{|l|}{ Abiotic Stress } & \multirow[b]{2}{*}{ Effects Described } & \multirow[b]{2}{*}{ References } \\
\hline & Type & MFs Applied & & \\
\hline Glycine $\max \mathrm{L}$. & Drought & $\begin{array}{l}\text { Static MF, } 200 \mathrm{mT} \\
\text { for } 1 \text { hour }\end{array}$ & $\begin{array}{l}\text { Enhanced plant growth, biomass } \\
\text { accumulation, photosynthetic } \\
\text { performance, photosynthetic pigment } \\
\text { content, efficiency of photosystem II, } \\
\text { photosynthesis rate, nitrate reductase } \\
\text { activity and yield }\end{array}$ & $\begin{array}{l}\text { Baghel et al. } \\
\text { (2018) }\end{array}$ \\
\hline Glycine $\max \mathrm{L}$. & Salinity & $\begin{array}{l}\text { Static MF, } 200 \mathrm{mT} \\
\text { for } 1 \text { hour }\end{array}$ & $\begin{array}{l}\text { Increased plant growth, biomass } \\
\text { accumulation and photosynthetic } \\
\text { performance. Improved the activity of } \\
\text { nitrogen fixation and leghaemoglobin } \\
\text { content and hemichrome content in the } \\
\text { root nodule }\end{array}$ & $\begin{array}{l}\text { Baghel et al. } \\
\text { (2016) }\end{array}$ \\
\hline Glycine $\max \mathrm{L}$. & $\begin{array}{r}10,20,30 \text { and } \\
40 \mathrm{mM} \mathrm{NaCl}\end{array}$ & $\begin{array}{c}\text { Pulsed MFs, } 0.1,1 \text {, } \\
10 \text { and } 100 \mathrm{~Hz}\end{array}$ & $\begin{array}{l}\text { Increased frequency of shoot and root } \\
\text { regeneration and number and length of } \\
\text { shoots and roots. Induced greater } \\
\text { number of roots and enhancement of } \\
\text { root length at } 40 \mathrm{mM} \mathrm{NaCl}\end{array}$ & $\begin{array}{l}\text { Radhakrishnan } \\
\text { and Kumari } \\
\text { (2013) }\end{array}$ \\
\hline
\end{tabular}


TABLE 9.1 (Continued)

Examples of Effects of Electromagnetic Fields of Plants Sown under Abiotic Stress

Conditions

$\begin{array}{cc}\text { Plant Species } & \begin{array}{c}\text { Abiotic Stress } \\ \text { Type }\end{array} \\ \text { Glycine max L. } & \begin{array}{c}\text { Salt stress } \\ (10 \mathrm{mM} \mathrm{NaCl})\end{array} \\ & \\ & \\ & \\ \text { Triticum aestivum } & \text { 60 g/L } \\ \text { (cv. Nina and } & \text { polyethylene } \\ \text { Flamura-85) } & \text { glycol (as a } \\ & \text { drought stress } \\ & \text { inducer) or } \\ & 100 \mathrm{mM} \text { NaCl } \\ & \text { (as a salinity } \\ & \text { stress inducer) }\end{array}$

\begin{tabular}{|c|c|c|}
\hline $\begin{array}{c}\text { Eucalyptus } \\
\text { globulus }\end{array}$ & $\begin{array}{l}\text { Heavy metal } \\
\text { toxicity (soil } \\
\text { containing } \mathrm{Cd} \text {, } \\
\mathrm{Hg}, \mathrm{Pb}, \mathrm{Zn}, \mathrm{Cr} \\
\text { and } \mathrm{Cu} \text { ) }\end{array}$ & $\begin{array}{l}\text { Static MFs, 30, 60, } \\
120,150 \text { and } 400 \\
\text { mT }\end{array}$ \\
\hline
\end{tabular}

Triticum aestivum Heavy metal toxicity (lead and cadmium)

Cucumis sativus Ultraviolet B $\left(3.5 \mathrm{~kJ} / \mathrm{m}^{2}\right.$ ultraviolet $\mathrm{B}$, $315 \mathrm{~nm}$ ) stress

\section{MFs Applied}

1.0-Hz uniform for 5 hours a day for 20 days

Static MF, 2.9-4.7 $\mathrm{mT}$ for 2.2 and $19.8 \mathrm{~s}$

Static MFs, 200, 400, 600 and 800 $\mathrm{mT}$ for $1 \mathrm{~ms}$

Static MFs, 0, 0.2 and $0.45 \mathrm{~T}$ pulsed MF, $1.5 \mu \mathrm{T}$

\section{Effects Described}

Increased calli fresh weight, total soluble sugar, total protein and total phenol contents.

Decreased ascorbic acid, lipid peroxidation and catalase activity. Enhanced calli tolerance to salt stress in terms of increase of flavonoids, flavones or flavonoles, alkaloids, saponin, total polyphenol, genistein and daidzein contents. Reduced overproduction of proline.

Improved plant growth. Increased the amount of superoxide radical and hydrogen peroxide in roots under drought stress or salt stress in total chlorophyll, chlorophyll a and chlorophyll b in leaves.

Enhanced antioxidant enzyme activities (superoxide dismutase, guaiacol peroxidase, catalase, ascorbate peroxidase and glutathione reductase) and total glutathione and oxidised glutathione contents.

Increased biomass yield. 150-mT MF improved the phytoremediation and alleviated the environmental risk, which shortened the time to purify $\mathrm{Cd}, \mathrm{Pb}$ and $\mathrm{Cu}$. Higher transpiration rate of plants along with exposure to static MFs induced lower soil moisture content and was beneficial to environmental control Increased germination by $600 \mathrm{mT}$ for 1 ms. Decreased catalase, superoxide dismutase, glutathione reductase activity, glutathione concentration and shoot biomass for 200, 400, 600 and $800 \mathrm{mT}$ for $1 \mathrm{~ms}$

Increased germination rate, seedling growth and development, lipid oxidation and ascorbic acid contents. Seed MF treatment increased the sensitivity of cucumber seedlings to ultraviolet-B radiation. Decreased seedling growth and development and actual quantum yield of photosystem II and increased oxidative pressure under combination of ultraviolet-B irradiation and MF

\section{References}

Radhakrishnan

et al. (2012)

Sen and Alikamanoglu (2016)

Luo et al. (2019)

Chen et al.

Yinan et al. 
effect was found in treated plants by absorbing more water (23.1\%), accumulating more proline (44.1\%) in their leaves and increasing the thickness (17.9\%) of their leaves. The treatment 170-mT MF for 15 min showed the best results (Karimi et al., 2012). Maize (Zea mays L.) plants from magnetically treated seeds with static MF of 100 and $200 \mathrm{mT}$ for 2 and 1 hour and sown under greenhouse conditions significantly enhanced seedling growth $(34.3 \%)$ and leaf water status (leaf water potential $(20.6 \%)$, turgor potential $(46.9 \%)$, relative water content $(3.5 \%)$ and photosynthesis rate $(71.4 \%)$ ) and lowered the antioxidant defence system (peroxidases $(50 \%)$ and catalase $(66.7 \%)$ ) of seedlings under soil drought stress (Anand et al., 2012).

Magnetic treatment has been found to provide protection of some plant species against salt stress without adversely affecting the environment. Pre-treated maize seeds with $200 \mathrm{mT}$ of static MF for 1 hour enhanced germination percentage (16\%), germination stress tolerance index $(23.2 \%)$, seedling vigour (70\%), growth parameters (plant height (41\%), leaf area (18\%) and biomass accumulation (137\%)), photosynthetic pigments content (46\%), the rate of photosynthesis (28\%) and stomatal conductance $(40 \%)$, which resulted in improved yield (29\%) of maize plants and decreased hydrogen peroxide $\left(\mathrm{H}_{2} \mathrm{O}_{2} ; 32 \%\right)$ under saline conditions (Baghel et al., 2019). A static MF of $35 \mathrm{mT}$ for $0.5 \mathrm{~min}$ caused an increase in all tested germination indexes (36.4\%), seedling growth (seedling shoot and root length (43.6\% and 46.8\%), seedling dry weight (23\%) and seedling vigour (18\%)), relative water content (19.6\%), salt tolerance index (10.2\%), antioxidant enzyme activity (peroxidase (15.6\%), polyphenol oxidase (24\%) and chitinase $(21.5 \%)$ ) and field performance characteristics of barley plants $(40.6 \%)$ in combination with water, proline or arginine under different salinity stress levels (324, 2,000, 4,000, 6,000 and 8,000 ppm; Hozayn et al., 2018).

Enhanced germination percentage (10\%-19\%) and early seedling growth (root and shoot length $(15 \%-40 \%$ and $18 \%)$ and vigour indexes $(40 \%)$ ), increased $\alpha$-amylase and protease activities $(15.4 \%-56.3 \%$ and $4 \%-10.5 \%)$ and increased levels of superoxide radical and hydrogen peroxide (13.8\%-31\% and 9.65-13.2\%) under different salinity levels $(0-100 \mathrm{mM} \mathrm{NaCl})$ were observed in maize and soybean plants grown from pre-treated seeds with static MF of $200 \mathrm{mT}$ for 1 hour as compared to control plants (Kataria et al., 2017a).

Sweet corn (maize) plants emerging from magnetically treated seeds using weak (15 mT) or strong (150 mT) MFs for 6, 12 and 24 hours showed an increase in germination rate and percentage $(5 \%-25.3 \%)$ and plant growth $(11.5 \%-13.4 \%)$ and a reduction in proline accumulation $(25.8 \%)$ by improving water absorption $(25.9 \%)$ under $\mathrm{NaCl}$ stress $(0,50$ and $100 \mathrm{mM})$. The highest germination rate was obtained by the stronger MF; however, the seedlings were more vigorous after treatment with 15-mT MF (Karimi et al., 2017).

Different experimental results have shown that MF treatment can ameliorate heavy metal toxicity stress in some crops. For example, mung bean seedlings treated with 600-mT MF under cadmium stress reduced the concentration of malondialdehyde (23.4\%-72.2\%), hydrogen peroxide $(25 \%-27.8 \%)$ and superoxide radical $(3.6 \%-22.1 \%)$ and the conductivity of electrolyte leakage (16.1\%-24.6\%), while the nitric oxide (NO) concentration $(33.3 \%-39.8 \%)$ and nitric oxide synthase (NOS) activity (13.3\%-22.2\%), photosynthesis rate (13.4\%) and growth parameters $(13.3 \%-22.6 \%)$ increased compared to cadmium stress alone, indicating that MF compensates for the toxicological effects of cadmium exposure and is related to NO signalling (Chen et al., 2011). A stimulating effect on the growth of spruce (Picea abies) seedlings (69\%) was observed for 50-Hz MF of $103 \mu \mathrm{T}$ and aluminium solution (in the form of $\mathrm{AlCl}_{3}$ ) of $100 \mu \mathrm{M}$, while slight positive responses were also found within the range of concentrations between 40 and $160 \mu \mathrm{M} \mathrm{Al}^{3+}$. These results suggest the importance of the synergistic action of the MF with metal aluminium stressor as well as the existence of physiological windows in addition to the frequency and power ones (Ruzic et al., 2000).

Some results demonstrated an alleviating effect of MF on ultraviolet light stress in plants. Exposure of sorghum seeds to a static MF of strength $125 \mathrm{mT}$ for 6 hours revealed a significant effect on the percentage of germinated seeds (34.8\%), speed of germination (40.5\%), seedling length (45\%) and number of leaves (14.4\%), while the MF application followed by immediate irradiation with ultraviolet- $C$ radiation at $254 \mathrm{~nm}$ for 30 and $60 \mathrm{~min}$ showed no significant effect on germination 
and seedling growth, indicating the magnetically untreated seeds with the exposure time $60 \mathrm{~min}$ of ultraviolet-C gave the highest seedling growth (Lazim and Nasur, 2017). A static MF of $200 \mathrm{mT}$ for 1 hour reduced the amount of hydrogen peroxide (36\%) and activities of antioxidant enzymes such as superoxide dismutase (38\%), glutathione reductase $(60 \%)$ and guaiacol peroxidase $(66 \%)$ of soybean (var. JS-335) plants that emerged from MF-treated seeds under ambient ultraviolet (280$400 \mathrm{~nm}$ ) stress compared to the control. The reduction in the hydrogen peroxide content (30\%) and antioxidant enzyme activities (40\%) after MF treatment and ambient ultraviolet exclusion indicated that solar ultraviolet components exert a significant stress on soybean plants. Similarly, the levels of ultraviolet-absorbing compounds $(14.6 \%-15 \%)$ were also decreased by exclusion of both ultraviolet and MF treatment. The results indicate that the exclusion of solar ultraviolet components and MF pre-treatment eliminates the need for defence against the ambient ultraviolet stress (Kataria et al., 2017b).

Some experimental results have exhibited a protective response of the MF against high temperatures or heat stress. The effects of pre-sowing magnetic treatments (MF of $120 \mathrm{mT}$ for $10 \mathrm{~min}$ and $80 \mathrm{mT}$ for $5 \mathrm{~min}$ ) on the growth and yield of tomatoes (cv. Vyta) increased notably root length (18\%), fresh and dry root weight (48.2\% and $80.7 \%)$, stem length (35.9\%), fresh and dry stem weight (39.6\% and $75.4 \%$ ), leaf area and foliole dry weight (39.3\% and 26.7\%), fruit number (21.3\%), mean fruit weight $(25.5 \%)$ and fruit yield per plant $(51.7 \%)$ and per area $(50.8 \%)$ under high temperature stress $\left(34^{\circ} \mathrm{C}\right.$ ) and under field conditions (De Souza et al., 2005). A weak sinusoidal and 50-Hz MF of $100 \mu \mathrm{T}$ alleviated the inhibitory effect of heat stress $\left(40,42\right.$ and $45^{\circ} \mathrm{C}$ for $\left.40 \mathrm{~min}\right)$ on the growth of cress seedlings (Lepidium sativum; 15\%) only when applied previously, whereas the application of MF alone and after heat stress did not produce any significant growth effects. It was also evident that with a stronger stress $\left(42^{\circ} \mathrm{C}\right.$ and $\left.45^{\circ} \mathrm{C}\right)$, the MF produced a more potent protective effect than at $40^{\circ} \mathrm{C}$, indicating the protective effect of MF against high temperatures (Ruzic and Jerman, 2002). These studies suggest that MF treatment ameliorates the adverse effects of drought, salinity, heavy metal toxicity, ultraviolet light and high temperatures.

\section{EFFECTS OF MFS ON BIOTIC STRESS}

Biotic stress in plants is caused by living organisms, especially viruses, bacteria, fungi, nematodes, insects, arachnids and weeds (Gull et al., 2019). These biotic stress agents cause various types of diseases, infections and damage to crop plants and ultimately affect the crop productivity. They depend on the environment and thus vary from region to region, from one agroecology to another, from one country to another country (Suzuki et al., 2014). Biotic stress plays a central role in regulating outbreaks of pests, pathogens, insects and weeds (McDonald et al., 2009; Peters et al., 2014; Ziska et al., 2010). Plants respond to biotic stress through a defence system, and this mechanism is classified as an innate and systemic response. After infection, reactive oxygen species (ROS) are generated and oxidative bursts limit pathogen spread (Atkinson et al., 2012). Several adaptive responses of plants have shown the role of MF on plant defence response under biotic stress conditions (Table 9.2).

Magnetic treatment has been found to protect some plant species against fungi, bacteria, phytoplasma and virus. For example, exposure to $0.2-\mathrm{mT}$ MF for $7 \mathrm{~min} 48 \mathrm{~s}, 11 \mathrm{~min} 42 \mathrm{~s}$ and $15 \mathrm{~min}$ $36 \mathrm{~s}$ on tomato seed infected by Fusarium sp. increased the rate of flowering (4.4\%), flower number (3.4\%), the rate of fruiting (2.8\%) and fruit number (11.\%), while the combination of MF exposure and seed soaking treatment enhanced flower number, the rate of fruiting and fruit numbers. 0.2-mT MF for $7 \mathrm{~min} 48 \mathrm{~s}$ showed the highest rate of flowering and the largest number of tomatoes, while 0.2-mT MF for $11 \mathrm{~min} 36 \mathrm{~s}$ exhibited the most number of flowers (13.4\%) and the highest rate of fruiting (5.1\%). However, soaking tomato seeds for $15 \mathrm{~min}$ before the $0.2-\mathrm{mT}$ MF treatment gave a better effect by increasing the rate of the plants to form flowers and fruits and increase the number of fruits (Agustrina et al., 2018).

A static MF of $0.1,0.5$ and $1 \mathrm{mT}$ decreased the growth of phytopathogenic microscopic fungal colonies by $10 \%$. At the same time, the number of developed conidia of Alternaria alternata and 


\section{TABLE 9.2}

\section{Examples of Effects of Electromagnetic Fields of Plants Sown under Biotic Stress Conditions}

\begin{tabular}{|c|c|c|c|c|}
\hline Plant Species & $\begin{array}{c}\text { Biotic Stress } \\
\text { Type }\end{array}$ & MFs Applied & Effects Described & References \\
\hline $\begin{array}{l}\text { Capsicum, } \\
\text { Zea mays }\end{array}$ & $\begin{array}{l}\text { Phytopathogenic } \\
\text { fungi } \\
\text { (Fusarium } \\
\text { oxysporum } \\
\text { conidia, } \\
\text { Alternaria } \\
\text { alternata and } \\
\text { Curvularia } \\
\text { inaequalis) }\end{array}$ & $\begin{array}{c}\text { Static MFs, } 0.1 \text {, } \\
0.5 \text { and } 1 \mathrm{mT}\end{array}$ & $\begin{array}{l}\text { Decreased the growth of phytopathogenic } \\
\text { microscopic fungi colonies and the number of } \\
\text { Fusarium oxysporum conidia. } \\
\text { Increased the number of developed conidia of } \\
\text { Alternaria alternata and Curvularia inaequalis. } \\
\text { MF influenced the formation of conidia }\end{array}$ & Pál (2005) \\
\hline $\begin{array}{l}\text { Nicotina } \\
\text { tobaccum }\end{array}$ & $\begin{array}{l}\text { Tobacco mosaic } \\
\text { virus }\end{array}$ & $\begin{array}{l}\text { Pulsed MFs (static } \\
\text { MFs of } 17 \text { and } 13 \\
\mu \mathrm{T} \text { combined } \\
\text { with a } 10-\mathrm{Hz} \\
\text { sinusoidal MF of } \\
25.6 \text { or } 28.9 \mu \mathrm{T} \text { ) }\end{array}$ & $\begin{array}{l}\text { Increased resistance in plants by a decrease in } \\
\text { lesion area and number, particularly after } \\
\text { magnetic treatment for } 8 \text { hours. } \\
\text { Increased ornithine decarboxylase and } \\
\text { phenylalanine ammonia-lyase activities involved } \\
\text { in resistance mechanisms, in particular for } 13-\mathrm{mT} \\
\text { static MF plus } 28.9-\mathrm{mT}, 10-\mathrm{Hz} \text { sinusoidal MF for } \\
24 \text { hours. } \\
\text { Enhanced hypersensitive response of tobacco to } \\
\text { tobacco mosaic virus }\end{array}$ & $\begin{array}{l}\text { Trebbi et al } \\
(2007)\end{array}$ \\
\hline
\end{tabular}

Curvularia inaequalis increased by 68\%-133\%, but the number of Fusarium oxysporum conidia decreased by $79 \%-83 \%$ (Nagy and Fischl, 2004).

The effect of MFs of modulated amplitude square waves in the frequency range $0.5-20 \mathrm{~Hz}$ for 24 hours reduced significantly the linear growth $(24.7 \%-56.5 \%)$ and biomass gain $(30.3 \%)$ of Sclerotium rolfsii in vivo and in vitro, the number of sclerotia (58.4\%), percentage of germination $(55 \%)$ and germ tubule length $(83.3 \%)$ of sugar beet plants. The sensitivity of the fungus for 24 hours counteracted the potency of fungus exposed to MFs of $0.5,5$ and $15 \mathrm{~Hz}$ which stimulated seedling emergency (7.8\%-77.1\%) in comparison with non-infested plants (Rizk, 2003).

Application of $10-\mathrm{Hz} \mathrm{MF}$ of $25 \mathrm{mT}$ for 1 hour affected the amylase activity of bacteria Rhodospirillum rubrum, which was verified by the increase in standard deviations $(250 \%)$ in distribution of the residual starch concentration. The use of 10-Hz MFs can regulate bacterial activity, and thus, 10-Hz MFs could be used for biotechnological application (Khokhlova and Vainshtein, 2017).

A significant delay in the appearance of first symptoms of geminivirus (7-9 days) and early blight (7-10 days) and a reduced infection rate (43\%-55.3\%) of early blight were found in the tomato plants grown from seeds exposed to increased MFs of $100 \mathrm{mT}$ for $10 \mathrm{~min}$ and $170 \mathrm{mT}$ for $3 \mathrm{~min}$ (De Souza et al., 2006). These findings indicate that MF triggers the plant defence response and protects plants against biotic stress. However, the mechanisms by which magnetic treatment protects the plants against the adverse effects of the abiotic and biotic stresses are still not fully understood.

\section{CONCLUSIONS AND PERSPECTIVES}

The seeds and plants treated with static and alternating MFs and PEMFs, from $1.5 \mu \mathrm{T}$ up to $800 \mathrm{mT}$ in the range of extremely low frequencies, showed an increase in seed vigour, plant growth and development, water relations, photosynthesis, accumulation of biomass and concentration of secondary 
metabolites and a decrease in free radicals as well as triggering the plant defence responses and antioxidant defence system under abiotic and biotic stress as well as non-stress conditions. This indicates that MF treatment improves tolerance or resistance to abiotic and biotic stresses. Therefore, an approach is revealed for ways to face the environmental stresses being generated by global warming and other causes that disturb agricultural efficiency. The MF treatment of seeds and plants may allow us to design more complex experiments to study the interaction between two or three different types of stress in order to better understand the net impact of stress combinations on plants.

The technology required to treat seeds and plants with MFs is a type of magnetic treatment in the range from 80 to $200 \mathrm{mT}$ for several exposure times (1-10 min; De Souza et al., 2006, 2010, 2014, 2020). This technology is appropriate and inexpensive for the small farmer with diverse crops; however, its application is limited at a larger scale and more research is therefore required to find ways to scale up the procedure.

\section{ACKNOWLEDGEMENTS}

The author wishes to thank Prof. Ben Greenebaum, University of Wisconsin-Parkside, for his valuable comments and suggestions on this chapter.

\section{REFERENCES}

Agustrina, R., Nurcahyani, E. and Irawan, B. (2018) Tomato generative growth from the seeds exposed to 0.2 mT of magnetic field and infected by Fusarium sp. J Phys Conf Ser 1116:052002.

Anand, A., Nagarajan, S., Verma, A., Joshi, D., Pathak, P. and Bhardwaj, J. (2012) Pre-treatment of seeds with static magnetic field ameliorates soil water stress in seedlings of maize (Zea mays L.). Indian J Biochem Biophys 49:63-70.

Atkinson, N.J., Lilley, V.J. and Urwin, P.E. (2013) Identification of genes involved in the response to simultaneous biotic and abiotic stress. Plant Physiol 162:2028-2041.

Baby, S.M., Narayanaswamy, G.K. and Anand, A. (2011) Superoxide radical production and performance index of Photosystem II in leaves from magnetoprimed soybean seeds. Plant Sign Behav 6:1635-1637.

Baghel, L., Kataria, S. and Guruprasad, K.N. (2016) Static magnetic field treatment of seeds improves carbon and nitrogen metabolism under salinity stress in soybean. Bioelectromagnetics 37:455-470.

Baghel, L., Kataria, S. and Guruprasad, K.N. (2018) Effect of static magnetic field pretreatment on growth, photosynthetic performance and yield of soybean under water stress. Photosynthetica 56:718-730.

Baghel, L., Kataria, S. and Jain, M. (2019) Mitigation of adverse effects of salt stress on germination, growth, photosynthetic efficiency and yield in maize (Zea mays L.) through magnetopriming. Acta Agrobot 72(1):1757.

Bolton, M.V. (2009) Primary metabolism and plant defense-fuel for the fire. Mol Plant Microbe Interact 22:487-497.

Brown, J.K.M. and Hovmoller, M.S. (2002) Aerial dispersal of pathogens on the global and continental scales and its impact on plant disease. Science 297:537-541.

Chen, Y., Li, R. and He, J.M. (2011) Magnetic field can alleviate toxicological effect induced by cadmium in mungbean seedlings. Ecotoxicology 20:760-769.

Chen, Y., Chen, D. and Liu, Q. (2017) Exposure to a magnetic field or laser radiation ameliorates effects of $\mathrm{Pb}$ and $\mathrm{Cd}$ on physiology and growth of young wheat seedlings. J Photochem Photobiol, B Biol 169:171-177.

De Souza, A., García, D., Sueiro, L., Licea, L. and Porras, E. (2005) Pre-sowing magnetic treatment of tomato seeds: Effects on the growth and yield of plants cultivated late in the season. Spanish J Agric Res 3(1):113-122.

De Souza, A., Garcia, D., Sueiro, L., Gilart, F., Porras, E. and Licea, L. (2006) Pre-sowing magnetic treatments of tomato seeds increase the growth and yield of plants. Bioelectromagnetics 27:247-257.

De Souza, A., Sueiro, L., García, D. and Porras, E. (2010) Extremely low frequency non-uniform magnetic fields improve tomato seed germination and early seedling growth. Seed Sci Technol 38:61-72.

De Souza, A., García, D., Sueiro, L. and Gilart, F. (2014) Improvement of the seed germination, growth and yield of onion plants by extremely low frequency non-uniform magnetic fields. Sci Hortic 176:63-69. 
De Souza, A., Sueiro-Pelegrin, L., Zambrano-Reyes, M., Macias-Socarras, I., Gonzales-Posada, M. and Garcia-Fernandez, D. (2020) Extremely low frequency non-uniform magnetic fields induce changes in water relations, photosynthesis and tomato plant growth. Int J Radiat Biol 96(7):951-957.

Fahad, S., Bajwa, A.A., Nazir, U., Anjum, S.A., Farooq, A., Zohaib, A., Sadia, S., Nasim, W., Adkins, S., Saud, S., Ihsan, M.Z., Alharby, H., Wu, C., Wang, C.D. and Huang, J. (2017) Crop production under drought and heat stress: Plant responses and management options. Front Plant Sci 8:1147.

Gull, A., Lone, A.A. and Wani, N.U.I. (2019) Biotic and Abiotic Stresses in Plants. In Alexandre Bosco de Oliveira (ed), Biotic and abiotic stresses in plants (pp. 1-6), IntechOpen, London. DOI: 10.5772/ intechopen.85832.

Heil, M. and Bostock, R.M. (2002) Induced systemic resistance (ISR) against pathogens in the context of induced plant defenses. Ann Bot 89:503-512.

Hozayn, M., EL-Mahdy, A.A. and Zalama, M.T. (2018) Magneto-priming for improving germination, seedling attributes and field performance of barley (Hordeum vulgare L.) under salinity stress. Middle East J Agric Res 7(3):1006-1022.

Javed, N., Ashraf, M., Akram, N.A. and Al-Qurainy, F. (2011) Alleviation of adverse effects of drought stress on growth and some potential physiological attributes in maize (Zea mays L.) by seed electromagnetic treatment. Photochem Photobiol 87(6):1354-1362.

Karimi, S., Hojati, S., Eshghi, S., Moghaddam, R.N. and Jandoust, S. (2012) Magnetic exposure improves tolerance of fig 'Sabz' explants to drought stress induced in vitro. Scientia Horticul 137:95-99.

Karimi, S., Eshghi, S., Karimi, S. and Hasan-Nezhadian, S. (2017) Inducing salt tolerance in sweet corn by magnetic priming. Acta Agric Slovenica 109(1):89-102.

Kataria, S., Baghel, L. and Guruprasad, K.N. (2017a) Pre-treatment of seeds with static magnetic field improves germination and early growth characteristics under salt stress in maize and soybean. Biocatal Agric Biotechnol 10:83-90.

Kataria, S., Baghel, L. and Guruprasad, K.N. (2017b) Alleviation of adverse effects of ambient UV stress on growth and some potential physiological attributes in soybean (Glycine max) by seed pre-treatment with static magnetic field. J Plant Growth Regul 36(3):550-565.

Khokhlova, G. and Vainshtein, M. (2017) Application of static and impulse magnetic fields to bacteria Rhodospirillum rubrum VKM B-1621. Khokhlova Vainshtein AMBExpr 7:60.

Lazim, S.K. and Nasur, A.F. (2017) The effect of magnetic field and ultraviolet-C radiation on germination and growth seedling of sorghum (Sorghum bicolor L. Moench). J Agric Vet Sci (IOSR-JAVS) 10(10):30-36.

Luo, J., He, W., Xing, X., Wu, J. and Gu, X.W.S. (2019) The phytoremediation efficiency of Eucalyptus globulus treated by static magnetic fields before sowing. Chemosphere 226:891-897.

Maron, J.L. and Crone, E. (2006) Herbivory: Effects on plant abundance, distribution and population growth. Proc R Soc B 273:2575-2584.

Massad, T.J., Dyer, L.A. and Vega, C.G. (2012) Cost of defense and a test of the carbon-nutrient balance and growth-differentiation balance hypotheses for two co-occurring classes of plant defense. PLoS One 7:e7554.

McDonald, A., Riha, S., DiTommaso, A. and DeGaetano, E. (2009) Climate change and the geography of weed damage: Analysis of US maize systems suggests the potential for significant range transformations. Agric Ecosyst Environ 130:131-140.

Mordecai, E.A. (2011) Pathogen impacts on plant communities: Unifying theory, concepts, and empirical work. Ecol Monogr 81:429-441.

Nagy, P. and Fischl, G. (2004) Effect of static magnetic field on growth and sporulation of some plant pathogenic fungi. Bioelectromagnetics 25:316-318.

Pál, N. (2005) The effect of low inductivity static magnetic field on some plant pathogen fungi. J Central Eur Agric 6(2):167-171.

Pandey, P., Ramegowda, V. and Senthil-Kumar, M. (2015) Shared and unique responses of plants to multiple individual stresses and stress combinations: Physiological and molecular mechanisms. Front Plant Sci $6: 723$.

Peters, K., Breitsameter, L. and Gerowitt, B. (2014) Impact of climate change on weeds in agriculture: A review. Agric Sustain Dev 34:707-721.

Prasch, C.M. and Sonnewald, U. (2013) Simultaneous application of heat, drought, and virus to Arabidopsis plants reveals significant shifts in signaling networks. Plant Physiol 162(4):1849-1866.

Radhakrishnan, R. and Kumari, B.D.R. (2013) Protective role of pulsed magnetic field against salt stress effects in soybean organ culture. Plant Biosyst 147(1):135-140. 
Radhakrishnan, R., Leelapriya, T., Ranjitha, B.D. and Kumari, D. (2012) Effects of pulsed magnetic field treatment of soybean seeds on calli growth, cell damage and biochemical changes under salt stress. Bioelectromagnetics 33:670-681.

Rizk, M.A. (2003) Possible control of sugarbeet pathogen Sclerotium rolfsii Sacc. by ELF amplitude modulated waves. Pakistan J Biol Sci 6(1):80-85.

Ruzic, R. and Jerman, I. (2002) Weak magnetic field decreases heat stress in cress seedlings. Electromagn Biol Med 21:69-80.

Ruzic, R., Vodnik, D. and Jerman, I. (2000) Influence of aluminum in biology effects of ELF magnetic field stimulation. Electro Magnetobiol 19(1):57-68.

Sen, A. and Alikamanoglu, S. (2016) Interactive effect of static magnetic field and abiotic stressors on growth and biochemical parameters of germinating wheat cultivars. IUFS J Biol 75(1):19-38.

Shao, H.B., Chu, L.Y., Jaleel, C.A. and Zhao, C.X. (2008) Water-deficit stress-induced anatomical changes in higher plants. C. R. Biol. 331:215-225.

Shine, M. and Guruprasad, K. (2012) Impact of pre-sowing magnetic field exposure of seeds to stationary magnetic field on growth, reactive oxygen species and photosynthesis of maize under field conditions. Acta Physiol Plant 34:255-265.

Shine, M., Guruprasad, K. and Anand, A. (2012). Effect of stationary magnetic field strengths of 150 and 200 $\mathrm{mT}$ on reactive oxygen species production in soybean. Bioelectromagnetics 33:428-437.

Strauss, S.Y. and Zangerl, A.R. (2002) Plant-insect interactions in terrestrial ecosystems. In Herrera, C.M. and Pellmyr, O. (eds), Plant-Animal Interactions: An Evolutionary Approach (pp. 77-106), Oxford: Blackwell Science.

Suzuki, N., Rivero, R.M., Shulaev, V., Blumwald, E. and Mittler, R. (2014) Abiotic and biotic stress combinations. New Phytol 203:32-43.

Swarbrick, P.J., Schulze-Lefert, P. and Scholes, J.D. (2006) Metabolic consequences of susceptibility and resistance in barley leaves challenged with powdery mildew. Plant Cell Environ 29:1061-1076.

Trebbi, G., Borghini, F., Lazzarato, L., Torrigiani, P., Calzoni, G.L. and Betti, L. (2007) Extremely low frequency weak magnetic fields enhance resistance of $\mathrm{NN}$ tobacco plants to tobacco mosaic virus and elicit stress-related biochemical activities. Bioelectromagnetics 28:214-223.

Verma, S., Nizam, S. and Verma, P.K. (2013) Biotic and abiotic stress signalling in plants. Stress Signaling Plants Genomics Proteomics Perspect 1:25-49.

Wang, W., Vinocur, B. and Altman, A. (2003) Plant responses to drought; salinity and extreme temperatures: Towards genetic engineering for stress tolerance. Planta 218:1-14.

Yinan, Y., Yuanm, L., Yongqing, Y. and Chunyang, L. (2005) Effect of seed pretreatment by magnetic field on the sensitivity of cucumber (Cucumis sativus) seedlings to ultraviolet-B radiation. Environ Exper Botany 54:286-294.

Ziska, L.H., Tomecek, M.B. and Gealy, D.R. (2010) Evaluation of competitive ability between cultivated and red weedy rice as a function of recent and projected increases in atmospheric $\mathrm{CO}_{2}$. Agron J 102:118-123. 